DOI: 10.4274/tpa.45.359

\title{
Doğumsal nazolakrimal kanal tıkanıklığında erken ve geç yaşlarda uygulanan lakrimal kanal masaj ve sondalama tedavisinin sonuçları
}

\author{
The outcomes of lacrimal massage or probing treatments at early \\ and late ages for congenital nasolacrimal duct obstruction
}

\author{
Çağatay Çağlar, Muhammed Batur*, Tekin Yaşar*, Adnan Çinal** \\ Başkale Devlet Hastanesi, Van, Türkiye \\ *Yüzüncü Yıl Üniversitesi Tıp Fakültesi, Göz Hastalıkları Anabilim Dalı, Van, Türkiye \\ ${ }^{\star *}$ Beyoğlu Göz Eğitim ve Araştırma Hastanesi, İstanbul, Türkiye
}

\section{Özet}

Amaç: Doğumsal nazolakrimal kanal tıkanıklığında yaş gruplarına göre lakrimal kanal masajı ve sondalamanın başarı oranlarını saptamak ve erken ve geç yaşlarda yapılan tedavinin sonuçlarını vurgulamak.

Gereç ve Yöntem: Nisan 2000 ve Mart 2009 tarihleri arasında, doğumsal nazolakrimal kanal tıkanıklığı tanısı almış 203 hastanın 294 gözü geriye dönük olarak incelendi. Hastalara yaş ve bulgularına göre lakrimal kanal masajı ve antibiyotik ya da genel anestezi altında sondalama ve yıkama tedavisi uygulandı. Olgular iki gruba ayrıldı: Grup 1 (lakrimal kanal masajı ve antibiyotik tedavisi uygulananlar) ve Grup 2 (sondalama ve yıkama tedavisi uygulananlar).

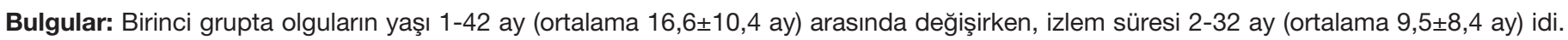
Tedavi tüm gözlerin \%53,7'sinde başarılı olurken, başarı oranı 0-6 aylık çocukların 25 gözünde \%96, 7-12 aylık çocukların 37 gözünde \%51,3, 13-18 aylık çocukların 30 gözünde \%53,3 ve 19-36 aylık çocukların 68 gözünde \% 39,7 idi. İkinci grupta olguların yaşı 9-84 ay (ortalama $24,5 \pm 13,1$ ay) arasında değişirken, izlem süresi 2-38 ay (ortalama 11,1 10,6 ay) idi. Bu grupta tedavi gözlerin \%86,5'inde başarılı olurken, başarı oranı 9-12 aylık çocukların 17 gözünde \%94,1, 13-18 aylık çocukların 44 gözünde \%93,1, 19-24 aylık çocukların 32 gözünde \%93,7, 25-36 aylık çocukların 25 gözünde \%84, 37-48 aylık çocukların yedi gözünde \%71,4 ve 49-84 aylık çocukların dokuz gözünde $\% 66,6$ idi.

Çıkarımlar: Lakrimal kanal masajı ve antibiyotik tedavisi 0-1 yaş grubunda ilk tedavi seçeneğidir. Şiddetli blefarit ve dakriyosistit bulguları olmadıkça 12 aydan önce sondalama işleminden kaçınılmalıdır. Biz hafif olgularda ve ailenin de isteği varsa sondalama tedavisinin 18 aya kadar geciktirilebileceğini düşünmekteyiz. Sondalama işlemi daha büyük çocuklarda da başarılı olup beş yaşına kadar uygulanabilir, ancak başarı oranı yaşla birlikte azalmaktadır. (Türk Ped Arş 2010; 45: 359-65)

Anahtar sözcükler: Doğumsal nazolakrimal kanal tıkanıklığı, lakrimal kanal masajı, sondalama.

\section{Summary}

Aim: To determine the success rates of lacrimal massage and probing according to age groups for congenital nasolacrimal duct obstruction (CNDO) and emphasize the outcomes of these treatments at early and late ages.

Material and Method: Between April 2000 and March 2009, two hundred and ninety-four eyes of 203 patients diagnosed with congenital nasolacrimal duct obstruction were retrospectively examined. According to symptoms and age, patients were treated with lacrimal massage and antibiotic therapy or probing and irrigation under general anesthesia. The cases were divided into two groups: Group 1 (lacrimal massage and antibiotic treatment) and Group 2 (probing and irrigation treatment).

Results: In group 1, the cases were 1-42 months of age (mean 16.6 \pm 10.4 months) and were followed-up 2-32 months (mean 9.5 \pm 8.4 months). Proportions of eyes treated successfully were $53.7 \%$ overall, $96 \%$ for the 25 eyes in children 0 to 6 months old, $51.3 \%$ for the 37 eyes in children 7 to 12 months, $53.3 \%$ for the 30 eyes in children 13 to 18 months, and $39.7 \%$ for the 68 eyes in children 19 to 36

Yazışma Adresi/Address for Correspondence: Dr. Çağatay Çağlar, Yüzüncü Yıl Üniversitesi Tıp Fakültesi, Göz Hastalıkları Anabilim Dall, Van, Türkiye E-posta: doktorcagatay@gmail.com Geliş Tarihi/Received: 22.02.2010 Kabul Tarihi/Accepted: 04.05.2010

Türk Pediatri Arşivi Dergisi, Galenos Yayınevi tarafindan basılmıştr. / Turkish Archives of Pediatrics, published by Galenos Publishing 
months. In group 2, the cases were 9-84 months of age (mean $24.5 \pm 13.1$ months) and were followed-up 2-38 months (mean $11.1 \pm 10.6$ months). Proportions of eyes treated successfully were $86.5 \%$ overall, $94.1 \%$ for the 17 eyes in children 9 to 12 months old, $93.1 \%$ for the 44 eyes in children 13 to 18 months, $93.7 \%$ for the 32 eyes in children 19 to 24 months, $84 \%$ for the 25 eyes in children 25 to 36 months, $71.4 \%$ for the 7 eyes in children 37 to 48 months, and $66.6 \%$ for the 9 eyes in children 49 to 84 months.

Conclusions: In the 0-1 age group, lacrimal massage and antibiotic treatment are the first therapeutic option. Early probing before 12 months of age should be refrained from unless symptoms such as dacryocystitis or severe blepharitis are presented. We consider that delay in probing is a viable option with mild symptoms up to the age of 18 months, or later if the parents wish it. Probing is successful in the older age group and can be performed up to the age of 5 years, but the success rates decrease with increasing ages of cases. (Turk Arch Ped 2010; 45: 359-65)

Key words: Congenital nasolacrimal duct obstruction, lacrimal massage, probing

\section{Giriş}

Doğumsal nazolakrimal kanal tıkanıklığı (DNKT) doğumdan sonraki ilk birkaç haftada gözyaşı göllenmesi ve dışarı akması, kese üzerine baskı ile mukoid salgı reflüsü, konjonktivit atakları, kirpik kenarlarında mukoid akıntı ve çapaklanmayla kendini gösteren bir klinik durumdur (1). Yenidoğanların yaklaşık \%20'sinde ilk bir ayda görülmesine karşın, bu olguların yaklaşık \%90'ında tıkanıklık lakrimal kanal masajılla ya da kendiliğinden ilk bir yılda açılmakta ve yakınmalar kaybolmaktadır $(2,3)$.

Sık görülmesine ve tedavi yöntemleri iyi tanımlanmış olmasına karşın uygulanacak tedavilerin alt ve üst yaş sınırları ile ilgili tartışmalar hala devam etmektedir. Bu çalışmada masaj+antibiyotik $(M+A)$ ile sondalama+basınçlı yıkama $(S+Y)$ tedavisi uygulamalarının yaşlara göre başarı oranı incelenmiş olup, bu tedavilerin normalde daha erken ve geç yapıldığı durumlardaki sonuçları tartışılmışıı.

\section{Gereç ve Yöntem}

Nisan 2000-Mart 2009 tarihleri arasında DNKT belirtileri ile başvuran hastaların kartları geriye dönük olarak incelendi. $\mathrm{M}+\mathrm{A}$ ve $\mathrm{S}+\mathrm{Y}$ uygulanan hastalardan iki ayrı grup oluşturuldu. İlk grupta $\mathrm{M}+\mathrm{A}$ tedavisi uygulanan 109 hastanın (64 erkek-\%58,72, 45 kı-\%41,28) 160 gözü yer alırken, 2. gruba $\mathrm{S}+\mathrm{Y}$ uygulanan 94 hastanın (53 erkek\%56,38, 41 kı-\% 43,62) 134 gözü dahil edildi. Doğumsal nazolakrimal kanal tıkanıklığı tanısı öykü ve klinik bulgular eşliğinde konuldu. Şüpheli olgulara floressein kaybolma testi yapıldı. Test için bir damla \% 1 'lik floressein solüsyonu her iki gözün alt konjonktival forniksine damlatıldı. Beş dakika süre geçmesine rağmen boyanın alt fornikste kalması gözyaşı akım sisteminde tıkanıklık yönünde değerlendirildi. Daha önce başka bir merkezde $S+Y$ ya da herhangi bir lakrimal cerrahi girişim öyküsü, nazolakrimal sistem travma öyküsü, gözyaşı kese mukoseli, dakriyokütanöz fistül, punktal ya da kanaliküler anomali, kraniyofasiyal anomalisi olan olgular çalışmaya alınmadı. Yapılacak işlemler ebeveynlere ayrıntılı olarak anlatıldı ve tüm olguların imzalı rızalı onam formları alındı.
Birinci grupta $(M+A)$ olgular tedavi yașına göre 0-6 ay, 7-12 ay, 13-18 ay ve olmak üzere dört gruba ayrıldı. Olgulara en az iki ay tedavi uygulandı. On iki aydan küçüklerde $\mathrm{M}+\mathrm{A}$ birincil tedavi olarak uygulanırken, 13 ay ve daha büyüklerde ise cerrahi işlemi kabul etmeyen, belirgin bulguları olmayan, aileyle konuşulup tedavide konservatif olarak yaklaşılan olgulara uygulandı. Masaj işlemi Crigler'in (4) tarif ettiği gibi işaret parmağı ortak kanalikül üzerine konulup daha sonra aşağı doğru sıvazlanarak günde 4-5×10 olacak şekilde uygulanmak üzere aileye öğretildi. Pürülan akıntı, çapaklanma ve bulber konjonktiva hiperemisiyle seyreden konjonktiviti olan olgularda ek olarak antibiyotik tedavisi ve antibakteriyel sıvıyla kirpik temizliği önerildi.

İkinci grupta $(S+Y)$ olgular tedavi yaşına göre 9-12 ay, 13-18 ay, $19-24$ ay, $25-36$ ay, 37-48 ay ve 48 aydan büyük olmak üzere altı gruba ayrıldı İkinci grupta sondalama laringeal maske ile inhalasyon anestezisi altında yapıldı. Teknik olarak üst punktum dilatatör ile genişletildikten sonra hastanın yaşına göre $0(0,94 \mathrm{~mm}$ çaplı) ya da 00 (1,10 mm çaplı) numaralı Bowman sondası ile punktumdan ampullaya kadar dikey girildi, buradan sonra 90 derece nazal yatay plana dönüldü, kanalikülde katlantı oluşmaması amacıyla üst kapak yana doğru çekildi. Sonda gözyaşı kesesinin nazal duvarı olan sonlanma bölgesine kadar ilerletildi. Daha sonra sonda $1 \mathrm{~mm}$ geri çekildi ve 90 derece aşağı ve hafif arkaya yöneltilerek açılma sesi hissedilinceye kadar alt meatusa ilerletildi. Pasaj açıklığını kontrol için serum fizyolojik ile hazırlanan yıkama sıvıSı ile nazolakrimal sistem yıkandı ve burun boşluğundan sıvı çekilerek ya da burun içinde alt meatus bölgesine konulan üçgen spanç yardımıyla geçiş kontrol edildi. Girişim sonrası bir hafta gentamisin damla $(4 \times 1)$, florometalon damla $(4 \times 1)$ verildi. Girişim sonrası bir hafta 1. ay, 2. ay ve daha uzun takip süresi olan olgularda daha sonraki muayene bulguları hasta dosyalarından kaydedildi.

Kontrollerde epifora varlığı muayene, öykü, ailenin verdiği öykü ve şüphede kalınan olgularda floressein kaybolma testi ile belirlendi ve buna göre işlemler tam başarıll, 
kısmi başarılı ve başarısız olarak üç gruba ayrıldı. Tam başarı $\mathrm{M}+\mathrm{A}$ ya da $\mathrm{S}+\mathrm{Y}$ tedavisinden sonraki iki ay içinde epiforanın tamamen durması, kısmi başarı ara ara özellikle soğuk ve rüzgarlı havalarda epifora oluşu, başarısızıı ise epiforanın devam etmesi olarak kabul edildi. Tam ve kısmi başarılı olgular sonuç olarak başarılı kabul edildi. $\mathrm{M}+\mathrm{A}$ tedavisi en az iki ay uygulandıktan sonra başarısız olan olgularda $\mathrm{S}+\mathrm{Y}$ yapıldı. Yine ilk $\mathrm{S}+\mathrm{Y}$ işlemi başarısız olan ve kontrole gelen olgularda en az iki ay sonra 2. kez işlem tekrarlandı.

İstatistiksel analiz SPSS 13.0 paket programı (LEAD Technologies Inc, USA, 2004) kullanılarak yapıldı. Sürekli değişkenler bakımından grupların karşılaştırılmasında Student $\mathrm{t}$ testi kullanıldı ve $\mathrm{p}<0,05$ anlamlı olarak kabul edildi.

\section{Bulgular}

\section{M+A Grubu}

Yüz dokuz hastanın 160 gözü çalışmaya alındı. Olguların özellikleri Tablo 1'de belirtilmiştir. Tüm yaş gruplarındaki hastalar dikkate alındığında başarı 86 gözde $(\% 53,7)$ (tam başarı \%37,5, kısmi başarı \%16,2), başarısızlık ise 74 gözde $(\% 46,3)$ izlendi. Erkek/kız başarı oranı ve sağ/sol göz ile çift gözlerdeki başarı oranı karşılaştıııldığında fark istatiksel olarak anlamlı değildi ( $p>0,05)$. Yaş gruplarına göre başarı oranları Tablo 2'de belirtilmiştir. On iki ay altında birincil tedavi olarak M+A uygulanan 62 gözde başarı oranı \%69,3 (tam başarı \%56,4, kısmi başarı
\%12,9) idi. On iki-36 ay yaş grubunda olmasına rağmen yukarıda belirtilen nedenlerle $\mathrm{M}+\mathrm{A}$ tedavisi yapılan 98 gözde başarı oranı ise \%43,8 (tam başarı \%25,5, kısmi başarı \%18,3) idi. İki grup arasında $M+A$ tedavisinin başarı oranları karşılaştııılığında fark istatiksel olarak anlamlı idi $(p<0,05)$. Yaş gruplarına göre başarı oranları ve diğer özellikler Tablo 2'de sunulmuştur.

\section{S+Y Grubu}

Doksan dört hastanın 134 gözü çalışmaya alındı. Olguların özellikleri Tablo 3'te belirtilmiştir. Tüm yaş gruplarındaki hastalar dikkate alındığında başarı 116 gözde $(\% 86,5)$, (tam başarı \%74,6, kısmi başarı \%11,9), başarısızlık ise 18 gözde $(\% 13,5)$ izlendi. Başarısız olan 18 gözün 8'inde 2. aydan sonra 2. kez sondalama yapıldı ve beşinde $(\% 62,5)$ başarı sağlandı. Erkek/kız başarı oranı ve sağ/sol göz ile çift gözlerdeki başarı oranı karşılaştııılıı̆ında fark istatiksel olarak anlamlı değildi $(p>0,05)$. On iki ay altında $S+Y$ uygulanan 17 gözde başarı oranı \%94,1 (tam başarı \%82,3, kısmi başarı \%11,8) idi. On üç ile 24 ay arası yaş grubundaki 76 gözde başarı oranı ise \% 93,4 (tam başarı \%73,7, kısmi başarı \%19,7) idi. Yirmi beş ay ve üstündeki yaş grubundaki 41 gözde başarı oranı ise \% 80,4 (tam başarı \%78, kısmi başarı \%2,4) idi. On iki ay altı ile 13-24 ay grubunda $\mathrm{S}+\mathrm{Y}$ tedavisinin başarı oranları arasındaki fark istatiksel olarak anlamlı değilken ( $p>0,05)$, bu iki grubun da 25 ay üstü grupla arasındaki fark istatiksel olarak anlamlı idi $(p<0,05)$. Yaş gruplarına göre başarı oranları ve diğer özellikler Tablo 4'te sunulmuştur.

\section{Tablo 1. Masaj+Antibiyotik tedavisi uygulanan hastaların özellikleri ve genel başarı oranları}

\begin{tabular}{|c|c|}
\hline Hastaların özellikleri & Sonuç \\
\hline Cinsiyet & 64 erkek/97 göz (\%58,7), 45 kı/63 göz (\% 41,3) \\
\hline Sağ/Sol göz oranı & 51 çift (\%46,5), 39 sol (\%36), 19 sağ $(\%$ 17,5) \\
\hline Ortalama başvuru yaşı (ay) & $16,6 \pm 10,4(1-42)$ ay \\
\hline Ortalama masaj süresi (ay) & $5,1 \pm 4,4 \quad(2-12)$ ay \\
\hline Ortalama izlem süresi (ay) & $9,5 \pm 8,4 \quad(2-32)$ ay \\
\hline Başarı oranı $\quad(n=160)$ & 86 göz (\%53,7) (60 tam başarı, 26 kısmi başarı) \\
\hline Erkek başarı oranı $(\mathrm{n}=97)$ & 49 göz $(\% 50,5)$ (34 tam başarı, 15 kısmi başarı) $(p>0,05)$ \\
\hline Kız başarı oranı $\quad(n=63)$ & 37 göz $(\% 58,7)$ (26 tam başarı, 11 kısmi başarı) $(p>0,05)$ \\
\hline Sağ göz başarı oranı $(n=19)$ & 9 göz $(\% 47,3)$ (5 tam başarı, 4 kısmi başarı) $(p>0,05)$ \\
\hline Sol göz başarı oranı ( $n=39)$ & 21 göz $(\% 53,8)(14$ tam başarı, 7 kısmi başarı) $(p>0,05)$ \\
\hline Çift göz başarı oranı ( $n=102)$ & 56 göz $(\% 54,9)$ (41 tam başarı, 15 kısmi başarı) $(p>0,05)$ \\
\hline
\end{tabular}

Tablo 2. Yaş gruplarına göre hastaların başarı oranları ve diğer özellikleri

\begin{tabular}{|l|c|c|c|c|}
\hline Hasta yaşı (ay) & Göz sayısı & Masaj süresi (ay) & İzlem süresi (ay) & Başarı oranı (\%) \\
\hline $0-6(4 \pm 1,7)$ & 25 & $4,8 \pm 4,2(2-12)$ & $17,8 \pm 9,9(2-30)$ & 96 \\
\hline $7-12(9,5 \pm 1,9)$ & 37 & $5,8 \pm 3,8(2-12)$ & $12,1 \pm 9,4(2-32)$ & 51,3 \\
\hline $13-18(15,3 \pm 2,3)$ & 30 & $4,7 \pm 4,1(2-16)$ & $5,5 \pm 3,8(2-13)$ & 53,3 \\
\hline $19-36(27,3 \pm 6)$ & 68 & $5,2 \pm 4,9(2-12)$ & $6,9 \pm 6(2-24)$ & 39,7 \\
\hline
\end{tabular}




\section{Tartışma}

Doğumsal nazolakrimal kanal tıkanıklığı çocuklarda epiforanın en sık sebebidir. Nazolakrimal yol doğumda kanallaşmasını henüz tamamlamamıştır ve \%70 olguda nazolakrimal kanal son bölümünde Hasner valvülünün delinmesinden dolayı membranöz tıkanıklık mevcuttur. Bu olgularında \%6-20 kadarı zamanla belirti verir $(5,6)$. Belirtiler doğumdan hemen sonra ortaya çıkabileceği gibi, en sık gözyaşı üretiminin olgunlaştığı yaşamın ilk birkaç haftasında ortaya çıkar. Bu olguların büyük bir kısmı kendiliğinden iyileşmekte ve yaklaşık \%1 kadarında tedaviye gereksinim duymaktadır. Genel olarak kabul gören tedavi şekli ilk bir yılda lakrimal kanal masajıyla birlikte enfeksiyon bulgularının görüldüğü aralıklı konjonktivit ataklarında antibiyotik tedavisinin başlanması, bir yaşını geçen olgularda ise kendiliğinden düzelmesini beklemek ya da ameliyathane şartlarında ve genel anestezi altında sondalama ile birlikte basınçla yıkanmasıdır. Yaşla birlikte kendiliğinden düzelmesi ve her iki tedavinin de başarı olasılığı azalmaktadır (7-10). Ayrıca her iki tedavinin de başarısını tıkanıklığın tipi ve yeri gibi nedenler de büyük oranda etkilemektedir (11). Büyük çocuklarda sondalama başarı oranının düşmesi hafif tıkanıkıkların kendiliğinden açılmasına, ileri yaş grubunda ise ciddi tıkanıklıkların birikmesine bağlanmaktadır (10-12). Ama kendiliğinden düzelme için ne zamana kadar bekleneceği, lakrimal kanal masaj tedavisinin ne kadar süre uygulandıktan sonra başarısız kabul edileceği, masaj gerçekten etkili yapıldığında bir yaşın üstündeki çocuklarda sondalamadan önce denenip denenemeyeceği, $S+Y$ tedavisinde yaşın üst sınıının kaç olduğu ve kaç yaşına kadar uygulanabileceği konularında tartışmalar hala sürmektedir.

Tablo 3. Sondalama+Basınçı Yıkama tedavisi uygulanan hastaların özellikleri ve genel başarı oranları

\begin{tabular}{|l|l|}
\hline Hastaların özellikleri & Sonuç \\
\hline Cinsiyet & 53 erkek/76 göz $(\% 56,4), 41 \mathrm{kız} / 58$ göz $(\% 43,6)$ \\
\hline Sağ/Sol göz oranı & 40 çitf $(\% 42,5), 28$ sağ $(\% 29,8), 26$ sol $(\% 27,7)$ \\
\hline Ortalama başvuru yaşı (ay) & $21,9 \pm 13,2(1-72)$ \\
\hline Ortalama masaj süresi (ay) & $24,5 \pm 13,1(9-84)$ \\
\hline Ortalama izlem süresi (ay) $\quad(n=160)$ & $11,1 \pm 10,6(2-38)$ \\
\hline Başarı oranı $\quad 116$ göz $(\% 86,5)(100$ tam başarı, 16 kısmi başarı) \\
\hline Erkek başarı oranı $\quad(n=97)$ & 68 göz $(\% 89,5)(58$ tam başarı, 10 kısmi başarı) $(p>0,05$ \\
\hline Kız başarı oranı $\quad(n=63)$ & 53 göz $(\% 91,3)(45$ tam başarı, 8 kısmi başarı) $(p>0,05)$ \\
\hline Sağ göz başarı oranı $(n=19)$ & 22 göz $(\% 78,5)(21$ tam başarı, 1 kısmi başarı) $(p>0,05)$ \\
\hline Sol göz başarı oranı $(n=39)$ & 24 göz $(\% 92,3)(20$ tam başarı, 4 kısmi başarı) $(p>0,05)$ \\
\hline Çift göz başarı oranı $(n=102)$ & 74 göz $(\% 92,5)(61$ tam başarı, 13 kısmi başarı) $(p>0.05)$ \\
\hline
\end{tabular}

Tablo 4. Yaş gruplarına göre hastaların başarı oranları ve diğer özellikleri

\begin{tabular}{|l|c|c|c|c|}
\hline Hasta yaşı (ay) & Göz sayısı & Sondalama zamanı (ay) & İzlem süresi (ay) & Başarı oranı (\%) \\
\hline $9-12(10,7 \pm 1,3)$ & 17 & $10,9 \pm 1,1(9-12)$ & $6,9 \pm 9,4(2-32)$ & 94,1 \\
\hline $13-18(13,1 \pm 5)$ & 44 & $15,4 \pm 1,8(13-18)$ & $9,2 \pm 8,2(2-38)$ & 93,1 \\
\hline $19-24(20,5 \pm 4,4)$ & 32 & $22,3 \pm 2,0(19-24)$ & $13,2 \pm 11,7(2-38)$ & 93,7 \\
\hline $25-36(27,0 \pm 8,7)$ & 25 & $32,1 \pm 4,1(25-36)$ & $15,3 \pm 12,2(2-33)$ & 84 \\
\hline $37-48(39,0 \pm 4,2)$ & 7 & $39,0 \pm 1,7(38-42)$ & $17,8 \pm 12,7(2-30)$ & 71,4 \\
\hline $48<\quad(54,8 \pm 9,4)$ & 9 & $57,5 \pm 12,6(49-84)$ & $25,8 \pm 11,3(7-36)$ & 66,6 \\
\hline
\end{tabular}

\section{Tablo 5. 48 ay'dan büyük çocukların özellikleri ve Sondalama+Basınçlı Yıkama tedavisinin başarısı}

\begin{tabular}{|c|c|c|c|c|c|c|}
\hline No & Başvuru yaşı (ay) & $S+Y$ yaşı (ay) & İzlem süresi (ay) & Cins & Sağ/Sol & Başarı \\
\hline 1 & 48 & 49 & 24 & $E$ & Sağ & $(+)$ \\
\hline 2 & 48 & 49 & 10 & $\mathrm{~K}$ & Sol & $(+)$ \\
\hline 3 & 48 & 50 & 36 & $E$ & Sağ & $(-)$ \\
\hline- & 48 & - & 36 & - & Sol & $(-)$ \\
\hline 4 & 48 & 51 & 7 & $E$ & Sol & $(+)$ \\
\hline 5 & 60 & 60 & 24 & $E$ & Sağ & $(+)$ \\
\hline \multirow[t]{2}{*}{6} & 60 & 60 & 36 & $\mathrm{~K}$ & Sağ & $(+)$ \\
\hline & 60 & - & 36 & - & Sol & $(+)$ \\
\hline 7 & 72 & 84 & 24 & $E$ & Sağ & $(-)$ \\
\hline
\end{tabular}




\section{Erken masaj+antibiyotik tedavisi}

Doğumsal nazolakrimal kanal tıkanıklığının tedavisinde ilk yıl içerisinde kendiliğinden düzelme oranı yüksektir $(13,14)$. Bu oran özellikle doğumdan sonraki ilk aylarda çok daha fazladır. MacEwen ve Young (14), 4792 süt çocuğunda yaptıkları çalışmada düzelen yaklaşık her üç olgudan ikisinin ilk altı ayda gerilediğini belirlemişlerdir. Daha sonraki aylarda ise başarı düşmektedir (14-16). Biz de çalışmamızda ilk altı ayda M+A başarısını \%96 olarak tespit ederken, 6. aydan sonra başarı oranının istatiksel olarak anlamlı bir şekilde \%51,3'e düştüğünü saptadık $(p<0,05)$. İlk 12 aydaki ortalama başarı ise çalışmamızda \%69,3 idi. Çiftçi ve ark.'ları da (17) benzer bir şekilde 350 göz üzerinde yaptıkları çalışmada 0-6 ay grubunda \%91,7, 6-12 ay grubunda ise $\% 60$ oranında başarı elde ettiklerini bildirmişlerdir. Bir başka çalışmada ise 7-12 aylık grupta başarı oranı \%10,6 gibi bir oranla son derece düşük bulunmuştur (18). IIlk 12 aydaki ortalama başarı oranı ise literatürde genel olarak yüksek bulunmuş olup $\% 80$ ile \%96 arasında bildirilmektedir $(13,14,16,19-21)$. Etkili lakrimal kanal masajın birçok hastada lakrimal içeriği aşağı iterek yararlı olduğu sintigrafik çalışmalarda gösterilmiş ve tedavide önerilmiştir (22). Sonuç olarak bu yaş grubunda $\mathrm{M}+\mathrm{A}$ etkili, maliyetsiz ve risksiz bir çözüm yöntemidir ve kanaatimizce öncelikli tedavi yöntemi olmalıdır.

\section{Geç masaj+antibiyotik tedavisi}

Literatürde 12 aydan sonra da $M+A$ başarısı ve kendiliğinden düzelmenin azımsanmayacak düzeyde olduğu sıkça tartışılmaktadır $(10,14,19,23,24)$. Young ve ark.'ları (25) 12-24 ay arasında $\mathrm{S}+\mathrm{L}$ başarısı ile kendiliğinden düzelme oranını karşılaştırmışlar ve bunları sırasıyla $\% 74$ ve $\% 60$ olarak bulmuşlardır. Düzelen 30 olgunun 24'ü $12-18$ ay grubunda, altısı ise 19-24 ay grubundadır. Bu çalıșma sonucunda 15. aydan daha küçük hastalarda $S+Y$ tedavisi kendiliğinden düzelmeye üstün bulunurken, 24 . ay sonunda kendiliğinden düzelme yine $\mathrm{S}+\mathrm{Y}$ başarısı daha fazla olmakla beraber anlamlı fark ortadan kalkmaktadır (25). Bazı yayınlarda şiddetli mukopürülan akıntı, mukosel gibi durumlar yoksa S+Y'nin 18 hatta 24 aya kadar geciktirilebileceği önerilmektedir (9). Hatta kendiliğinden düzelmenin 48 aya kadar görülebileceği bildirilmiştir (23). Bir başka çalışmada da 13-24 aylık grupta $M+A$ tedavisinin başarı oranı \%79,3 olarak bulunmuştur (19). Bizim çalışmamızda da $M+A^{\prime}$ 'nın 13-18 aylık grupta başarı oranı, 7-12 aylık gruptakine benzer şekilde \%50'lerde seyretmiştir. Bu oran aynı yaş gruplarında $\mathrm{S}+\mathrm{Y}$ tedavisinin başarı oranları ile karşılaştııılıı̆ında (\%94 ve \%93), istatiksel olarak anlamlı derecede düşük olsa da $(p<0,05)$, genel anestezi riskleri göz önüne alındığında özellikle sulanması az ve daha önce herhangi bir tedavi almamış bazı seçilmiş olgularda denenebilir. Uzamış enflamasyonun tıkalı alanlarda fibrozu artırmayacağının gösterilmiş olması bu tür hastalarda cerrahinin geciktirilebileceğini ortaya koymaktadır (26).

\section{Erken sondajlama+basınçla yıkama tedavisi}

Literatürde erken $\mathrm{S}+\mathrm{Y}$ tedavisini öneren birçok çalıșma vardır ve özellikle erken başvuran ve şiddetli blefarit ve dakriyosistit bulguları olan olgularda uzun süreli lakrimal kanal masaj tedavisine rağmen şikayetler geçmezse $\mathrm{S}+\mathrm{Y}$ tedavisi bir yaşından önce yapılabilir $(25,27)$. Çalışmamızda 12 ayın altında olan 11 hastanın 18 gözünde ortalama 3,7 (3-6) aylık başarılı olmayan $\mathrm{M}+\mathrm{A}$ tedavisinin ardından $\mathrm{S}+\mathrm{Y}$ uygulandı. Olguların tümünde bulgular belirgindi. Bu gözlerin biri hariç hepsinde başarı sağlandı. Tüm altı yaş grubunda yaptığımı $\mathrm{S}+\mathrm{Y}$ tedavisinin en başarılı olduğu grup bu yaş grubuydu $(\% 94,1)$. Bu grupta başarı oranı çalışmamızda olduğu gibi literatürde de yüksek olarak bulunmuş olup, \%92-100 arasında değişmekte idi (2,27-29). Başarı oranı yüksek olsa da bu yaş grubunda yapılan $S+Y$ 'nin riskleri de vardır. Yapılan sondalama işleminin lakrimal epitele zarar verip darlığa sebep olarak daha sonra da kendiliğinden düzelmeyi önleme olasılığı vardır (9). Başarısız ilk sondalamadan sonra darlık oranının \%44'lere ulaştığı bildirilmiştir (30). Kanama kanaliküler sistemde travmanın işaretidir ve sondalamadan sonra hastaların \%20'sinde görülmektedir. Üstelik genel anesteziden kaynaklanan riskler de mevcuttur. Bu yaş grubunda $\mathrm{S}+\mathrm{Y}$ tedavisi başarısız birkaç aylık $\mathrm{M}+\mathrm{A}$ tedavisi sonrasında genel anestezi riski yoksa, özellikle kontrole gelemeyecek veya bulguları belirgin olgularda ilk yılın son aylarında uygulanabilir. Ayrıca 7-12 ay grubunda masaj tedavisinin başarı oranının çalışmamızda \%51,3, buna karşın $\mathrm{S}+\mathrm{Y}$ başarı oranının \%94,1 saptanması nedeniyle, birkaç ay uygulanan ve başarısız olan lakrimal kanal masajından sonra ilk yılın son aylarında vakit kaybetmeden $\mathrm{S}+\mathrm{Y}$ tedavisi uygulanması doğru bir yöntem olarak görünmektedir.

\section{Geç sondajlama+basınçla yıkama tedavisi}

Sondalama işleminin çok geç yaşlarda dahi başarılı olabileceği gösterilmiştir. Erdem ve ark.'larının (2) çalışmasında 24-60 ay grubunda başarı \%90,8'dir. Robb'da (30) 24-35 ay grubunda $\% 96,4,36$ ay ve üstü grupta \%92,6 oranında başarı bildirilmiştir. Bu yüksek başarı oranlarına rağmen 24 ay ve üstü grupta başarıyı Young ve ark.' 'ları (25) \%54, Özdemir ve ark.'ları (31) \%50 olarak tespit etmiştir. Honavar ve ark.'Iarı (5) ise 24 ay ve üstü (24-186 ay, ortalama 33 ay) grupta çalışmamızdaki oranlara benzer oranlar bulmuşlar ve ilk sondalama sonunda $\% 73,3$, ikinci sondalama sonunda ise $\% 80$ başarıya ulaşmışlardır. Çocuk göz hastalıkları araştırma grubunun yaptığı bir çalışmada da başarı 24-36 ay grubunda \%79, 36-48 ay grubunda \%56 bulunmuştur (32). Daha büyük çocuklarda başarı incelendiğinde; 3-10 yaş arasındaki çocuklardaki başarı oranlarını inceleyen bir çalışmada bu oran \%75 olarak bulunmuştur (33). Yine 48 aydan büyük çocuklarla yapılan bir başka çalışmada ise başarı oranı \%69,2'dir (34). Literatürde yedi yaşında dahi başarı elde edilen olgular bildirilmiştir (35). Çalışmamızda 
biri tek diğeri çift taraflı olmak üzere beş yaşında iki olgunun üç gözünde başarı sağlanırken, yedi yaşındaki bir olgunun bir gözünde işlem başarısız oldu. Kırk sekiz aydan büyük çocuklardaki S+Y sonuçlarımız Tablo 5'te belirtilmiştir.

Görüldüğü gibi literatürde geç sondalamanın başarı oranları çok değişken olmakla birlikte genelde \%50'nin üzerindedir. Literatürde genel olarak $12-24$ ay grubunda başarı oranları benzerdir. 25-36 ay grubunda da başarı bu gruba yakındır. Bu aydan sonra ise başarının belirgin oranda azaldığı görülmektedir $(6,18,28,32,34,35)$. Çalışmamızda da 24 aydan küçük ama farklı yaşlardaki çocuklarda başarı oranları benzerken, 24 ay sonrası dönemde başarı oranı belirgin bir şekilde düşmektedir. Yirmi dört ay altı 93 gözde başarı \%93,6 iken, 24 ay üstü 41 gözde ise \%78'dir. Birçok yayında ve çalışmamızda gösterildiği gibi büyük çocuklarda dahi S+Y'nin başarılı sonuçlar vermesi daha girişimsel tedavilere geçilmeden önce $S+Y$ 'nin denenmesi gerektiğini göstermektedir. Bizim önerimiz beş yaşına kadar bu işlemin uygulanabileceğidir.

Bazı olgularda tıkanıklık karmaşıklık yaratmakta ve bu tür hastalar ne $M+A$ ne de $S+Y$ uygulamasına rağmen iyileşmemektedir. Bu tür olgularda balon kateterle genişletme, bikanaliküler silikon tüp entübasyonu ve dakriyosistorinostomi gibi ek girişimler uygulanmalıdır. Bu tedavilerle başarı oranları \%100'e ulaşmaktadır (36). Çalışmamızda her iki tedavinin de başarısız olduğu ve izlemeye devam edilen hastaların 18 gözüne ek girişimler uygulanmıştır.

\section{Başarıyı sağlayan etmenler}

Çalışmamızda başarıyı etkileyen etmenlerden yaş, cinsiyet, iki gözün birden tutulması ve önceki $M+A$ tedavisine yanıtsızlık incelenmiştir. Çalışmamızda yaşla birlikte başarının azaldığı gruplar arasındaki istatistiksel anlamlılık farklarından anlaşılmıştır. Bu durumun daha ciddi tıkanıklıkların geç yaşlara doğru birikmesinden kaynaklandığını düşünmekteyiz. Bazı çalışmalarda cinsiyet farklılığı ya da iki gözün birden tutulması kötü seyir etmeni olarak tesbit edilmemiştir. Çalışmada incelediğimiz bir başka etmende $M+A$ yapılıp başarısız olan olgularda bu tedavinin daha sonra yapılan S+Y'ye etkisi idi. Başarısız $\mathrm{M}+\mathrm{A}$ tedavisinin ardından $\mathrm{S}+\mathrm{Y}$ yapılan 43 hastanın 62 gözündeki başarıya bakıldığında oran; 7-12 aylık grupta \% $84,13-18$ aylık grupta $\% 93$ ve 19 ay ve üstü grupta ise $\% 88$ idi. Masaj+Antibiyotik yapılmadan doğrudan olarak $\mathrm{S}+\mathrm{Y}$ yapılan gruplarda ise sırasıyla bu oran $\% 100, \% 95,8$ ve \%89,6 idi. Masaj yapılmadan sondalama yapılan her üç grupta da başarı oranları daha yüksek olmasına rağmen, her üç grup arasındaki fark istatistiksel olarak anlamsız idi $(p>0,05)$. Daha önce yapılan masaj tedavisi başarısız olan olgularda başarısızlığın sebebi karmaşık bir tıkanıklık olup, ardından yapılan sondalamanın da başarısının bu karmaşık tıkanıklıktan dolayı daha az olduğunu düşünüyoruz.

\section{Sonuç olarak önerilerimiz şunlardır}

1. Illk altı ayda mutlaka hasta $M+A$ ile takip edilmelidir. $\mathrm{Bu}$ dönemde kendiliğinden düzelme oranı çok yüksek olup, M+A tedavisiyle izlenen hastalarda başarı \%100'e yaklaşmaktadır.

2. Olguların yaş aralığı 7-12 ay ise yine $M+A$ ile izlenmeli ama şiddetli sulanma, dakriyosistit gibi durumlar varsa ve uzun süreli $\mathrm{M}+\mathrm{A}$ tedavisine rağmen iyileşmezse karmaşık bir tıkanıklık düşünülüp $S+Y$ yapılabilir.

3. Tartışmalı olan 13-18 aylık grupta ise iki seçenek vardır; Başarı oranı yüksek ama girişimsel sayılabilecek S+Y ve başarı oranı göreceli olarak daha düşük ama girişimsel olmayan $\mathrm{M}+\mathrm{A}$ tedavisi. Bu durumda yine bulgular ve ailenin kararı önemlidir. Biz hafif ve daha önce tedavi almamış olgularda 18. aya kadar en az iki ay $M+A$ ile izlem öneriyoruz.

4.18 aydan büyük çocuklarda $S+Y$ tedavisi yapılmalıdır. Anestezi için risk varsa 24. aya kadar beklenebilir, $\mathrm{S}+\mathrm{Y}$ beş yaşına kadar denenebilir.

5. Masaj+antiyobitik uygulanırken her olguya antibiyotikli damla reçete edilmemelidir. Antibiyotik şiddetli mukopürülan akıntı ve kırmızı göze neden olan akut konjonktivit dönemlerinde kullanılmalı ve kirpik temizliği ile desteklenmelidir. Hafif akıntı ve göz beyaz olarak gözlemlendiğinde antibiyotik kesilmelidir. Lakrimal kanal masajı aileye doğru öğretilmeli ve desteklenmelidir. Biz masaj tedavisine başladığımız hastalarda aylık kontrollerle masajın doğru yapılıp yapılmadığını kontrol ediyoruz.

6. Sondajlama+basınçlı yıkama tedavisi genel anestezi altında yapılır ve anestezinim tüm riskleri bu girişimde de geçerlidir. Ayrıca zorlamayla yanlış yol açılması (işlem sırasında kanama genelde yanlış yol açılmasında olur) ve lakrimal kanal epitelinin hasara uğraması sonucu skar oluşumu gibi durumlar ciddi iyatrojenik komplikasyonlardır ve kendiliğinden düzelme olasılığını azaltır (37). Dolayısıyla tedavi usta ellerde uygulanmalı, zorlanmamalı ve işlem sırasında dikkatli ve nazik olunmalıdır.

\section{Kaynaklar}

1. Katowitz JA, Kropp TA. Congenital abnormalities of the lacrimal drainage system. In: Hornblass A, ed. Oculoplastic, Orbital and Reconstructive Surgery. Baltimore: Williams and Wilkins, 1990: 1397-416.

2. Kapadia MK, Freitag SK, Woog JJ. Evaluation and management of congenital nasolacrimal duct obstruction. Otolaryngol Clin North Am 2006; 39: 959-77.

3. Zilelioğlu G, Uğurbaş SH. Konjenital nazolakrimal kanal tıkanıklığının tedavisi. T Klin Oftalmoloji 1999; 8: 290-4.

4. Crigler LW. The treatment of congenital dacryocystitis. JAMA 1923; 81: 23-4.

5. Zwaan J. The anotomy of probing and irrigation for congenital nasolacrimal duct obstruction. Ophthalmic Surg and Lasers 1997; 28: 71-3.

6. Young JD, MacEwen CJ. Managing congenital lacrimal obstruction in general practice. BMJ 1997; 315: 293-6. 
7. Honavar SG, Prakash VE, Rao GN. Outcome of probing for congenital nasolacrimal duct obstruction in older children. Am J Ophthalmol 2000; 130: 42-8.

8. Zilelioğlu G, Hoșal BM. The results of late probing in congenital nasolacrimal duct obstruction. Orbit 2007; 26: 1-3.

9. Sarı A, İsmi T, Adıgüzel U, Yıldırım Ö. Konjenital nazolakrimal kanal tıkanıklıklarında başarıyı etkileyen faktörler ve geç sondalama. MN Oftalmoloji 2009; 16: 126-30.

10. Paul TO, Shepherd R. Congenital nasolacrimal duct obstruction: Natural history and the timing of optimal intervention. $J$ Pediatr Strabismus 1994; 31: 362-7.

11. Kushner BJ. Congenital nasolacrimal system obstruction. Arch Ophthalmol 1982; 100: 597-600.

12. Kashkouli MB, Beigi B, Parvaresh MM, Kassaee A Tabatabaee Z. Late and very late inital probing for congenital nasolacrimal duct obstruction: What is the cause of failure? $\mathrm{Br}$ J Ophthalmol 2003; 87: 1151-3.

13. Paul TO. Medical management of congenital nasolacrimal duct obstruction. J Pediatr Ophthalmol Strabismus 1985; 22: 68-70.

14. MacEwen CJ, Young JD. Epiphora during the first year of life. Eye 1991; 5: 596-600.

15. Wagner RS. Management of congenital nasolacrimal duct obstruction. Pediatr Ann 2001; 30: 481-8.

16. Kakizaki H, Takahashi Y, Kinoshita S, Shiraki K, Iwaki M. The rate of symptomatic improvement of congenital nasolacrimal duct obstruction in Japanese infants treated with conservative management during the 1 st year of age. Clin Ophthalmol 2008; 2: 291-4.

17. Çiftçi $F$, Akman A, Sönmez M, Unal M, Güngör A, Yaylali V. Systematic combined treatmant approach to nasolacrimal duct obstruction in different age groups. Eur $\mathrm{J}$ Ophthalmol 2000; 10: 324-9.

18. Özkurt A. Konjenital dakriyostenozlarda hidrostatik masaj, basınçlı lavaj ve sonda uygulamaları. T Klin Oftalmoloji 1998; 7: 197-200.

19. Nucci $P$, Capoferri $C$, Alfarano R, Brancato R. Conservative management of nasolacrimal duct obstruction. J Pediatr Ophthalmol Strabismus 1989; 26: 39-43.

20. Piest KL, Katowitz JA. Treatment of congenital nasolactrimal duct obstruction. Ophthalmol Clin North Am 1991; 4: 201-9.

21. Yaman A, Berk AT, Söylev MF. Doğumsal nazolakrimal kanal tıkanıklığında tedavi sonuçlarımız. T Klin Oftalmoloji 2004; 13: 159-64.

22. Foster JA, Katowitz JA, Heyman S. Results of dacryoscintigraphy in massage of the congenitally blocked nasolacrimal duct. Ophthal Plast Reconstr Surg 1996; 12: 32-7.
23. Castelo BNE, Castelo BB, Cardoso CC, Carvalho RG, Mota E, Castelo Branco A. Management of congenital nasolacrimal duct obstruction. Arq Bras Oftalmol 2009; 72: 75-8.

24. Schellini SA, Ferreira RSC, Jaqueta E, Padovani CR, Padovani $\mathrm{CR}$. Spontaneous resolution in congenital nasolacrimal obstruction after 12 months. Semin Ophthalmol 2007; 22: 71-4.

25. Young JD, MacEwen CJ, Ogston SA. Congenital nasolacrimal duct obstruction in the second year of life, a multicentre trial of management. Eye 1996; 10: 485-91.

26. MacEwen CJ, Phillips MG, Young JD. Value of bacterial culturing in the course of congenital nasolacrimal duct obstruction. J Pediatr Ophthalmol Strabismus 1994; 31: 246-50.

27. Katowitz JA, Welsh MG. Timing of initial probing and irrigation in congenital nasolacrimal duct obstruction. Ophthalmology 1987; 94: 698-705.

28. Esgin H, Özgür S, Erda S. Doğumsal nazolakrimal kanal tıkanıklıklarında sondalama zamanı. T Klin Oftalmoloji 1999; 8: 56-9.

29. Erdem E, Tök Ö, Akbaş KF, Nurözler AB, Örnek F. Doğumsal nazolakrimal kanal tıkanıklığında sondalama zamanı. T Oft Gaz 2009; 38; 180-4.

30. Robb RM. Success rates of nasolacrimal duct probing at time intervals after 1 year of age. Ophthalmology 1998; 105: 1307-10.

31. Özdemir M, Yaşar T, Özçimen M, Çinal A. Konjenital nazolakrimal kanal tıkanıklı̆ında sonda-lavaj zamanlaması. T Oft Gaz 2002; 32: 592-5.

32. Repka MX, Chandler DL, Beck RW, et al. Pediatric Eye Disease Investigator Group. Primary treatment of nasolacrimal duct obstruction with probing in children younger than 4 years. Ophthalmology 2008; 115: 577-84.

33. Thongthong K, Singha P, Liabsuetrakul T. Success of probing for congenital nasolacrimal duct obstruction in children under 10 years of age. J Med Assoc Thai 2009; 92: 1646-50.

34. Abrishami M, Bagheri A, Salour SH, Mirdehghan SA. Late probing for congenital nasolacrimal duct ob struction. J Ophthalmic Vis Res 2009; 4: 102-4.

35. Maheswari R. Success rate and cause of failure for late probing for congenital nasolacrimal duct obstruction. J Pediatr Ophthalmol Strabismus 2008; 45: 168-71.

36. Repka MX, Chandler DL, Holmes JM, et al. Pediatric Eye Disease Investigator Group. Balloon catheter dilation and nasolacrimal duct intubation for treatment of nasolacrimal duct obstruction after failed probing. Arch Ophthalmol 2009; 127: 633-9.

37. Lyon DB, Dortzbach RK, Lemke BN, et al. Canalicular stenosis following probing for congenital nasolacrimal duct obstruction. Ophthalmic Surg 1991; 22: 228-32. 